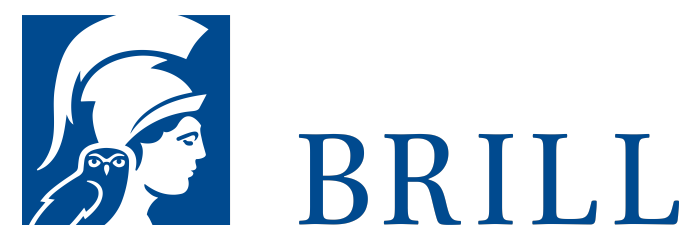

\title{
Der ewige Albtraum
}

Zur Figur des Kriegsheimkehrers in der Literatur des 20. und 21. Jahrhunderts

Author: Jonas Nesselhauf

Der aus dem Krieg zurückkehrende Soldat ist eine paradigmatische Sozial- und Reflektionsfigur des 20. und frühen 21. Jahrhunderts und seit dem Ersten Weltkrieg vielfach in Kunst und Literatur verhandelt worden.

Seit 1914 nicht nur Millionen junger Männer in den ersten »Massenkrieg« der Moderne einzogen, sondern auch unzählige Soldaten verwundet oder traumatisiert wieder nach Hause zurückgekommen sind, wurde die literarische Figur des Kriegsheimkehrers zu einer dauerhaften Erscheinung in den europäischen und nordamerikanischen Literaturen. Die Untersuchung widmet sich in dieser Form zum ersten Mal in der deutschsprachigen Forschung der literarischen Figur des Kriegsheimkehrers aus komparatistischer Perspektive, schlägt dabei den Bogen vom Ersten Weltkrieg bis zum »War on Terror « und bringt fiktionale Prosatexte aus Deutschland, Frankreich, Großbritannien, Italien, Spanien, Russland/der Sowjetunion und den USA zusammen.

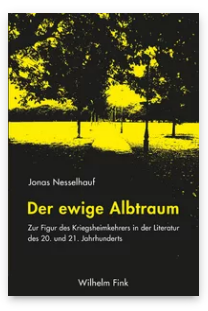

Pages: 353

Seiten, $1 \mathrm{~s} / \mathrm{w}$

Abb.

Language:

German

Subjects:

General,

Literature and

Cultural Studies

Publisher: Brill |

Fink

E-Book (PDF)

Released online:

17 Nov 2017

ISBN: 978-3-

8467-6200-4

List price

Paperback

Publication date:

10 Nov 2017

ISBN: 978-3-

7705-6200-8

List price 
Studium der Allgemeinen und Vergleichenden

Literaturwissenschaft sowie Kunstgeschichte an der Universität des Saarlandes. Promotion mit einer komparatistischen Arbeit zur Figur des Kriegsheimkehrers in der Literatur des 20. und 21. Jahrhunderts an den Universitäten Vechta und Saarbrücken. Derzeit PostDoc-Mitarbeiter am Department III der Universität Vechta in den Fächern Kulturwissenschaften und Germanistik.

For more information see brill.com

Order information: Order online at brill.com +44330 333 o049 | customerservices@brill.com Submission information: brill.com/authors

Titles published by Brill | Fink, Brill | mentis or Brill | Schöningh: +49(o)71 5413279216 | brill@brocom.de 